\title{
Viral Infection of Tissue Cultured Orchids and Evaluation of Damages
}

\author{
Bong Nam Chung ${ }^{1 *}$, Ju-Yeon Yoon ${ }^{2}$ and Mi Sun Kim ${ }^{1}$ \\ ${ }^{1}$ National Institute of Horticultural and Herbal Science, Rural Development Administration, Suwon 440-310, Korea \\ ${ }^{2}$ Institute of Natural Science, Seoul Women's University, Seoul 139-724, Korea
}

(Received on January 11, 2010; Accepted on May 5, 2010)

\begin{abstract}
Most orchids are propagated by tissue culture. To survey the viral infection of tissue cultured Orchids, total RNA was extracted from in vitro Cymbridium and Phalaenopsis spp. collected from companies producing tissue-cultured orchids, and RT-PCR analysis was conducted with primer pairs specific to Cymbidium mosaic virus (CymMV) and Odontoglossum ring spot virus (ORSV), which are infecting wide range of orchid genera. The bulb size of Cymbidium infected with CymMV and ORSV was compared with healthy one at 10 months after planting in vitro orchids in the glasshouse. The CymMV or ORSV infection in 97 Cymbidium and 55 Phalaenopsis plants was 84.5 and $89.1 \%$, respectively. Mixed infection was found in 52.6 and $47.3 \%$ of Cymbidium and Phalaenopsis tested, whereas virus-free orchids were 15.5 and $10.9 \%$, respectively. The CymMV and ORSV reduced the bulb size by $2.7-50 \%$ depending on the cultivars of Cymbidium. The both viruses caused yellowing, mottle and mosaic with or without necrosis in 4 Cymbidium cultivars.
\end{abstract}

Keywords : CymMV, ORSV, RT-PCR, tissue culture, virus

Orchid, one of the most important potted floricultural crops in Korea, commands a cultivation area of 332 ha in 2005. It accounts for $25.8 \%$ in terms of the potted floricultural crop cultivation area. Thirty kinds of viruses have been reported on orchids worldwide (Lawson and Hsu, 1995). Among them, Cymbidium mosaic virus (CymMV) and Odontoglossum ringspot virus (ORSV) are the most prevalent in Korea (Chang et al., 1991; Park et al., 1998; Ryu et al., 1998). CymMV causes chlorotic or necrotic symptoms on orchid leaves and flowers. The infected flowers become deformed and exhibit color breaking in Cymbidium. ORSV induces streak or striped mosaic or ringspots on leaves (Chang et al., 1991).

Most orchids are generally propagated by tissue culture methods of axillary buds and shoot meristems. For vegetative propagation of Phalaenopsis by tissue culture, inter-

\footnotetext{
*Corresponding author.

Phone) +82-31-290-6236, FAX) +82-31-290-6259

E-mail)chbn7567@korea.kr
}

nodal sections of flower stalks are usually used worldwide including Korea (Homma and Asahira, 1985). In Cymbidium, shoot meristems are usually used, and they are multiplied upto 10,000 plants in vitro. There are limit in number in propagation by tissue culture, because over than 10,000 plants per meristem might cause genetic variation. From the reason new meristem must be excised from field-grown orchids for every 10,000 plants.

To investigate virus infection status of in vitro Cymbidium and Phalaenopsis, RT-PCR was carried out with primer pairs specific to CymMV and ORSV. Primer pairs were as follows; CymMVK-F (5'-ACAATAATTTGAAATAATCATGGGA-3') and CymMVK-R (5'-AAAACCACACGCCTTATTAAGTTTG-3'), and ORSVK-F (5'-ACGCACAATCTGATTCGTATTGAA-3') and ORSVK-R (5'-TATCAACGTTATTTTCCTAAATAT-3'). For duplex RT-PCR in one reaction tube, $10 \mathrm{ng}$ of total RNA in $8 \mu \mathrm{L}$ of nuclease free water and $1 \mu \mathrm{L}$ of 10 pmole CymMVK-R and ORSVK$R$ primers for reverse transcription were heated at $70^{\circ} \mathrm{C}$ for 5 min followed by adding $4 \mu \mathrm{L}$ of $5 \times$ reaction buffer, 2.5 $\mathrm{mM} \mathrm{MgCl} 2,0.25 \mathrm{mM}$ of each dNTP, $1 \mu \mathrm{L}$ of Improm II reverse transcriptase (Promega, USA) on ice, and incubating at $37^{\circ} \mathrm{C}$ for $1 \mathrm{hr}$. PCR amplification was performed in a $50 \mu \mathrm{L}$ volume containing $20 \mu \mathrm{L}$ of the cDNA solution, 0.2 $\mathrm{mM}$ of each dNTP, $2 \mathrm{mM} \mathrm{MgCl} 2,10$ pmole reverse and forward primers for each virus, 2.5 units of GoTaq DNA polymerase (Promega, USA), and the $10 \mu \mathrm{L}$ of $5 \times$ PCR buffer. The thermocycler program consisted of 1 cycle at at $94^{\circ} \mathrm{C}$ for $2 \mathrm{~min}, 30$ cycles at $94^{\circ} \mathrm{C}$ for $30 \mathrm{sec}, 50^{\circ} \mathrm{C}$ for $1 \mathrm{~min}$, $72^{\circ} \mathrm{C}$ for $1 \mathrm{~min}$, followed by a final extension at $72^{\circ} \mathrm{C}$ for 10 min. Total 97 Cymbidium and 55 Phalaenopsis collected from companies propagating orchids by tissue culture in Korea were surveyed by RT-PCR as described above. The amplified products were $716 \mathrm{bp}$ for CymMV and $528 \mathrm{bp}$ for ORSV (Fig. 1).

The CymMV and/or ORSV infection in Cymbidium and Phalaenopsis was 84.5 and $89.1 \%$, whereas virus-free plants were lower to 15.5 and $10.9 \%$, respectively (Fig. 1, Table 1). High percentage of orchids was mixed infected by CymMV and ORSV in this survey. ORSV was more prevalent than CymMV (Table 1). This result was coincident with the observation of Park et al. (1998) where infection 

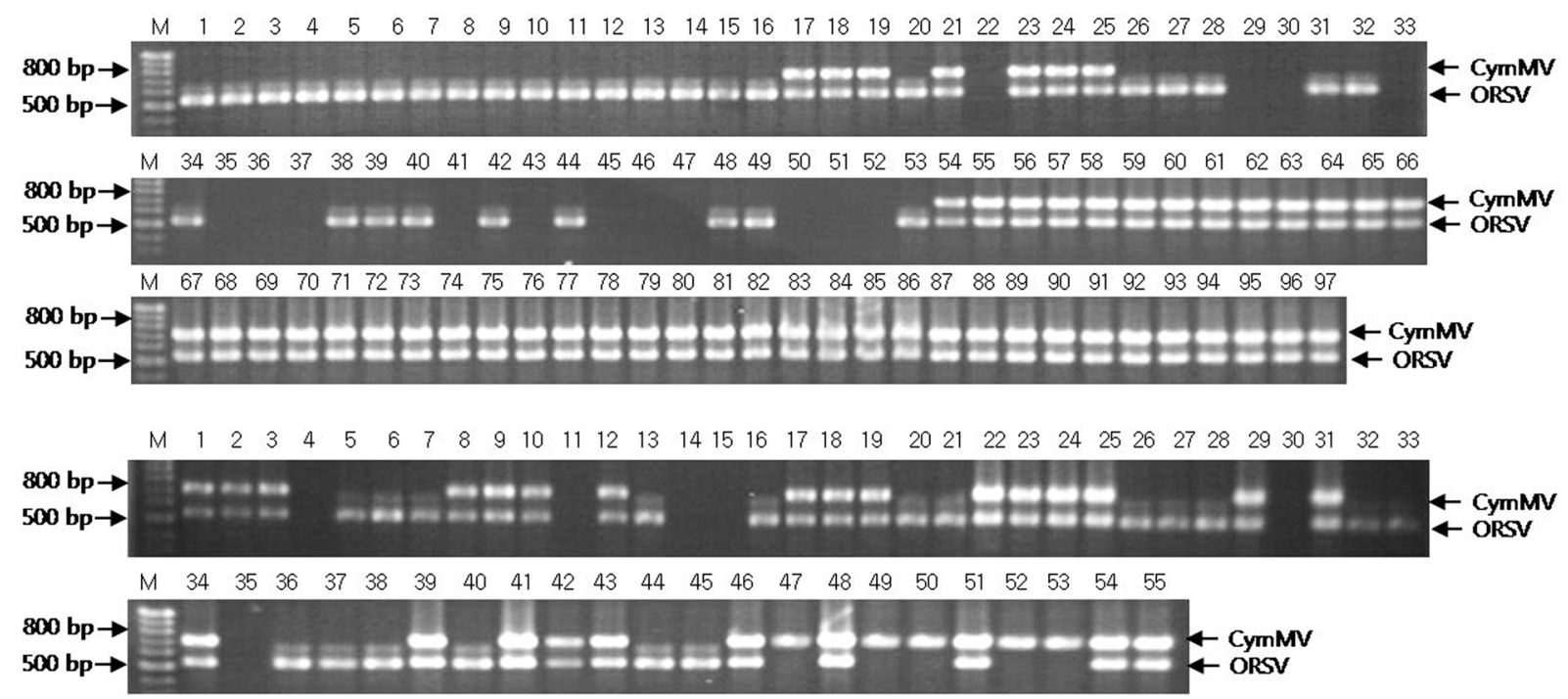

Fig. 1. Detection of CymMV and ORSV from in vitro orchids by duplex RT-PCR. The cDNA fragments synthesized from viral RNAs were amplified in one tube with primer pairs both of CymMVK-F and CymMVK-R for CymMV and ORSVK-F and ORSVK-R for ORSV detection. The sizes of PCR product are $716 \mathrm{bp}$ and $528 \mathrm{bp}$, respectively. All orchid samples were collected from orchid cultivation company in Korea. A. Cymbidium sp. Lane 1-16: A company, lane 17-25: B company, lane 26-53: C company and lane 54-97: D company. B. Phalaenopsis sp. Lane 1-45: E company, lane 46-55: F company.

Table 1. Virus infection rate of CymMV and ORSV in tissue cultured Cymbidium sp. and Phalaenopsis sp.

\begin{tabular}{|c|c|c|c|c|c|c|c|}
\hline \multirow[b]{2}{*}{ Orchids } & \multirow{2}{*}{$\begin{array}{l}\text { Source of } \\
\text { sample }^{b}\end{array}$} & \multirow{2}{*}{$\begin{array}{l}\text { No. of plants } \\
\text { tested }\end{array}$} & \multirow[b]{2}{*}{ CymMV } & \multicolumn{4}{|c|}{ Infection rate $(\%)^{\mathrm{a}}$} \\
\hline & & & & ORSV & $\begin{array}{c}\text { CymMV } \\
\text { and ORSV }\end{array}$ & $\begin{array}{c}\text { Virus } \\
\text { infected }\end{array}$ & $\begin{array}{l}\text { Virus } \\
\text { free }\end{array}$ \\
\hline \multirow{4}{*}{ Cymbidium sp. } & A & 16 & 0.0 & 100.0 & 0.0 & 100.0 & 0.0 \\
\hline & $\mathrm{B}$ & 9 & 0.0 & 11.1 & 77.7 & 88.8 & 11.2 \\
\hline & $\mathrm{C}$ & 28 & 0.0 & 50.0 & 0.0 & 50.0 & 50.0 \\
\hline & $\mathrm{D}$ & 44 & 0.0 & 0.0 & 100.0 & 100.0 & 0.0 \\
\hline Sub-total & & 97 & 0.0 & 40.0 & 52.6 & 84.5 & 15.5 \\
\hline \multirow{2}{*}{ Phalaenopsis sp. } & $\mathrm{E}$ & 45 & 0.0 & 40.0 & 46.7 & 86.7 & 13.3 \\
\hline & $\mathrm{F}$ & 10 & 50.0 & 0.0 & 50.0 & 100.0 & 0.0 \\
\hline Sub-total & & 55 & 9.0 & 32.7 & 47.3 & 89.1 & 10.9 \\
\hline Total & - & 152 & 8.3 & 33.5 & 45.7 & 87.5 & 12.5 \\
\hline
\end{tabular}

${ }^{a}$ RT-PCR was used for detection of CymMV or ORSV.

${ }^{\mathrm{b}}$ Companies producing tissue cultured orchids.

rate of ORSV and CymMV in field collected orchids was 15.5 and $22.4 \%$, respectively. This data indicated not only virus infected Cymbidium and Phalaenopsis have been used for tissue culture but also CymMV and ORSV do not easily removed by meristem tip culture at least in Cymbidium, because presently Cymbidium has been propagated in vitro by excision of meristem tips in Korea. In Thailand, CymMV and ORSV were detected in $65.4 \%$ and $0 \%$ of Dendrobium. On the contrary to Korea, CymMV was a prevalent virus in Dendrobium in Thailand (Kehntry et al., 2006).
Tissue culture of meristem tips have been popularly used for obtaining virus-free plants. Although meristem was excised from field-cultivated plants, it would not guarantee to be virus-free condition. When meristem tip culture was firstly used to produce virus-free plants, it was assumed that the regenerated plants were healthy since viruses did not invade the meristematic tissues of the bud (Kassanis, 1965), despite the fact that Tobacco mosaic virus (TMV) was reported to be present in meristems of tomato (Sheffield, 1942). CymMV was eliminated from CymMV and ORSVinfected meristem tissue pieces less than 0.2-0.5 mm, 
Table 2. Comparison of the bulb size in Cymbidium infected with CymMV and/or ORSV

\begin{tabular}{cccc}
\hline \hline Cultivar & Division & $\begin{array}{c}\text { No. of plants } \\
\text { investigated }\end{array}$ & $\begin{array}{c}\text { Diam. of bulb } \\
(\mathrm{mm})\end{array}$ \\
\hline \multirow{3}{*}{ Moon } & Healthy & 3 & $25.4 \pm 0.1$ \\
flight & CymMV & 1 & 12.4 \\
& ORSV & 4 & $16.8 \pm 0.3$ \\
& CymMV+ORSV & 4 & $12.2 \pm 0.2$ \\
\hline \multirow{5}{*}{ Yellow } & Healthy & 1 & 23.2 \\
butterfly & CymMV & 1 & 13.8 \\
& ORSV & 2 & $15.9 \pm 0.1$ \\
& CymMV+ORSV & 6 & $17.2 \pm 0.3$ \\
\hline \multirow{4}{*}{ Moon } & Healthy & 4 & $22.6 \pm 0.2$ \\
stone & CymMV & 4 & $14.5 \pm 0.4$ \\
& ORSV & 0 & - \\
& CymMV+ORSV & 6 & $22.0 \pm 0.4$ \\
\hline \multirow{5}{*}{ Silk road } & Healthy & 0 & - \\
& OymMV & 1 & 16.1 \\
& ORSV & 4 & $20.7 \pm 0.2$ \\
\hline & CymMV+ORSV & 0 & - \\
\hline
\end{tabular}
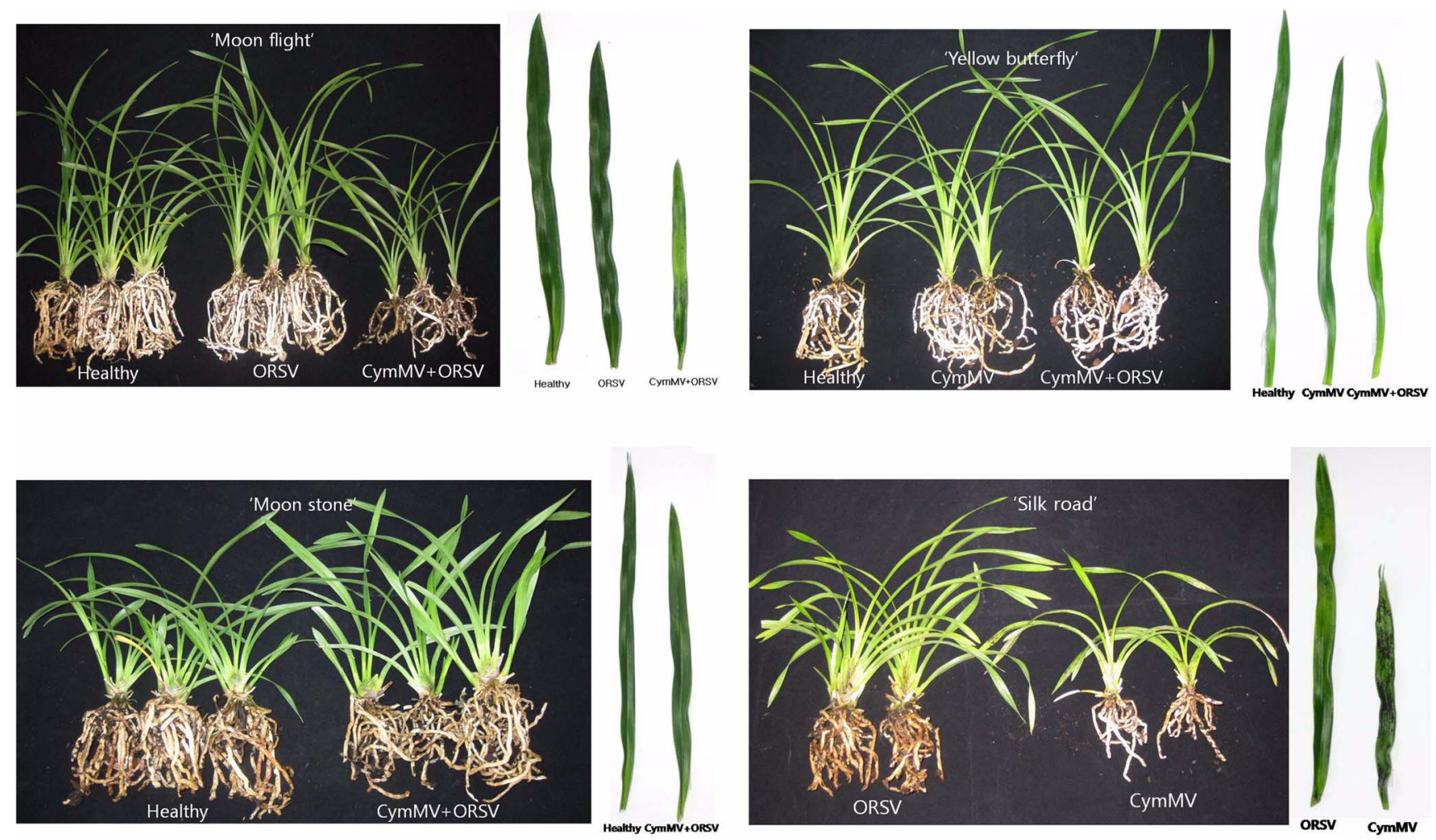

Fig. 2. Symptomatology in 4 Cymbidium cultivars infected with CymMV and/or ORSV. The Cymbidium cultivars showed reduction in growth vigor and revealed symptoms of yellowing, mottle and necrosis on leaves. A. 'Moon flight', B. 'Yellow butterfly', C. 'Moon stone' and D. 'Silk road'. 
CymMV. Further experiments are need with more replication. Common result from all Cymbidium cultivars tested was that CymMV affected more severely than ORSV, and CymMV and/or ORSV reduced the bulb size and growth vigor in all Cymbidium cultivars tested (Fig. 2). Typical viral symptoms such as yellowing with mottle was observed on leaves of cultivars Moon flight, Yellow butterfly and Moon stone doubly infected with both viruses, and black necrosis on leaves of 'Silk road' single infected with CymMV (Fig. 2).

This study showed that high percentage of in vitro orchids was infected with CymMV and/or ORSV. This result indicated that most tissue culture companies of orchids do not use virus-free plants for tissue culture, because simple excision of meristem tips from virus-infected Cymbidium is mostly resulted in fail to remove CymMV and ORSV. Result of the reduction of bulb size and growth vigor in Cymbidium by infection with CymMV or/and ORSV in this study showed the need for producing virusfree Cymbidium to produce high-quality plants and export to other countries with strict quarantine conditions.

\section{Acknowledgments}

This work was supported by the "Cooperative Research Program for Agricultural Science \& Technology Development (Project No. PJ006308)", Rural Development Administration (RDA), Korea Research Foundation Grants funded by the Korean Government (MOEHRD-KRF2007-359-F00001 and MOEHRD, Basic Research Promotion Fund, KRF-2008-314-F00009), and Agenda Program Grants (200901010600310010200) of the RDA,
Republic of Korea.

\section{References}

Chang, M. U., Chun, H. H., Baek, D. H. and Chung, J. D. 1991. Studies on the viruses in orchids in Korea. 2. Dendrobium mosaic virus, Odontoglossum ringspot virus, Orchid fleck virus, and unidentified potyvirus. Korean J. Plant Pathol. 7:118-129.

Homma, Y. and Asahira. T. 1985. New means of Phalaenopsis propagation with internodal sections of flower stalks. J. Japan. Soc. Hort. Sci. 54:379-387.

Ishii, M. 1974. Partial elimination of virus from doubly infected orchids by meristem explants culture. Acta Hort. 36:229-234.

Kassanis, B. 1965. Therapy of virus infected plants. J. R. Agric. Soc. Engl. 126:105-114.

Khentry, Y., Paradornuwat, A., Tantiwiwat, S., Phansiri, S and Thaveechai, N. 2006. Incidence of Cymbidium mosaic virus and Odontoglossum ringspot virus in Dendrobium spp. in Thailand. Crop Protect. 25: 926-932.

Lawson, R. H. and Hsu, H. T. 1995. Orchid. In: Virus and Viruslike Diseases of Bulb and Flower Crops. Ed. by G Loebenstein, R. H. Lawwon and A. A. Brunt, pp. 409-420, John Wiley \& Sons, N. Y.

Park, W. M., Shim, K. B., Kim, S. J. and Ryu, K. H. 1998. Detection of Cymbidium mosaic virus and Odontolossum Ringspot virus by ELISA and RT-PCR from cultivated orchids in Korea. Korean J. Plant Pathol. 14:130-135.

Ryu, K. H., Kim, S. J. and Park, W. M. 1998. Incidence of cymbidium mosaic virus and odontoglossum ringspot virus in Cymbidium and other orchids in Korea. J. Kor. Soc. Hort. Sci. 39:213-217.

Sheffield, F. M. L. 1942. Presence of virus in the primordial meristem. Anпu. Appl. Biol. 29:16-17. 